\title{
Research on the Teaching Ability Structure of Middle School Teachers Under the Information Technology
}

\author{
Wanqiu Liang \\ College of Foreign Languages of Yanbian University \\ Yanji, China 133002
}

\begin{abstract}
Under the teaching background of promoting the comprehensive integration of science technology and curriculum, the future education informatization will make the teaching process full of variety. However, in the tide of informatization teaching, there are still many middle school teachers having lagged concept of informatization teaching, poor ability in integration of teaching resources and low informatization teaching level. Based on literature analysis and empirical research, this paper studies the teaching ability of teachers at home and abroad on the promotion of information science technology, analyzes the change and developing trend of teachers' ability structure and the current situation of information teaching ability structure of middle school teachers, makes new interpretation of the teaching ability structure of middle school teachers according to the requirements of informatization teaching idea, resource integration ability and teaching implementation ability for them, and finally puts forward a strategy to optimize the teaching ability of middle school teachers, that is, broadening the channels of improving teaching ability of middle school teachers, such as via training, independent learning, internet-assisted teaching research, etc. to improve the informatization teaching ability of middle school teachers in the new era.
\end{abstract}

Keywords-information technology environment; middle school teachers; teaching ability structure

\section{INTRODUCTION}

Driven by the informatization construction in China, the teaching technology level has been gradually improved and the network teaching has been widely popularized in middle schools, which breaks the existing control to teaching, greatly enhances the teaching efficiency of teachers and the learning efficiency of students and also brings new change for schools in teaching mode. For example, teachers can implement inverted classroom teaching by using microlectures and carry out classroom teaching and online discussion by using education cloud platforms; students can carry out independent learning by using mobile terminals such as tablet PC; in the use process, the interactive electronic whiteboard only plays a role of display, and its interactive function cannot be fully used. For traditional teachers, the various new teaching modes and problems arising from them are new and new challenge. However, in real teaching environment, especially in the primary and secondary schools in backcountry, most of the teachers are not fully prepared ideologically and technologically; for them, the integration of information technology and curriculum integration advocated by the national competent department is just a form and has not been normalized and used in teaching; the platform resources purchased by the schools has not been effectively used, and students are still provided with the traditional classroom and traditional homework. In fact, information technology provides technical support for the reform of teaching mode, so that the teaching can pay more attention to the individualized development of students and highlight the dominant role of students. Therefore, middle school teachers should be able to adapt to the development of the times and improve their teaching ability under the information environment, which has been a problem they have to face correctly. Then, what abilities the teaching ability includes under the information environment, and how could they improve such abilities? Obviously, it has become a new topic of modern teaching information-based development to explore the informatization teaching ability structure of teachers and optimize the structure.

\section{CURRENT SITUATION OF RESEARCH ON INFORMATIZATION TEACHING ABILITY AT HOME AND ABROAD}

Informatization teaching is a process of analyzing the teaching process from the perspective of information technology application. Compared with the traditional teaching mode, informatization teaching is a new teaching mode based on the application of information technology and one of its distinguishing features is that it is supported by computer technology and communication technology. In this mode, middle school teachers are required to have the ability to apply information technology to promote their ability in innovation of their own teaching awareness, teaching method and skills. In other words, under the information technology environment, middle school teachers should have a certain informatization teaching ability so as to promote the deep integration of teaching content and information technology.

In the field of traditional teacher knowledge, teachers are required to have professional disciplinary knowledge (that is, content knowledge) and related psychological and pedagogical knowledge (that is, pedagogy knowledge). In the process of teaching, teachers mainly focus on "propagating the doctrine, imparting professional knowledge and resolving doubts"; the teaching contents are mainly textbooks and outlines, which are relatively single; and the teaching means 
is blackboard-writing. With the continuous development of information technology in the 21 st century, teachers in the new era are required to have the ability of information teaching -- "technology, pedagogy and content knowledge". Through analysis of the many-sidedness, situationality and complexity, the paper holds that good teaching requires teachers to be able to effectively combine the technology, pedagogy and content knowledge. Based on this requirement, the teaching emphasizes students as the center and highlights students' dominant role in the teaching process, while teachers gradually transform from the dominant of classroom teaching to the guide for students in the process of active learning.

\section{REQUIREMENTS FOR THE INFORMATIZATION TEACHING ABILITY STRUCTURE OF MIDDLE SCHOOL TEACHERS}

\section{A. Strengthening the Informatization Teaching Idea}

In the teaching environment of the information age, first, the information-based teaching technology can provide new teaching environment, new teaching equipment and new teaching methods for school teaching, such as micro class and inverted classroom [1]. Informatization teaching should reflect and highlight the dominant role of the students, and teachers should make full use of information technology to realize ubiquitous teaching, which is conducive to the individualized development of students. Meanwhile, the promotion of informatization teaching ability can also become a standard to evaluate teachers' qualification.

Second, information technology should be fully integrated with courses in the informatization teaching class, so as explore new teaching mode under the information background and improve teachers' informatization teaching ability. Only in this way can the advantages of education information technology be fully reflected in the teaching process.

Third, informatization teaching can provide high-quality, fast and convenient digital education resources which can effectively support teachers' teaching activities and give full play to the advantages of information technology. Therefore, schools should provide teachers with good teaching resources through multiple channels and ways, and encourage teachers to fully develop scholastic resources and remote education resources.

Last, the informatization teaching idea focuses on improving the application of education information. Only education information is fully used in detail and in place can the advantages of information technology be fully exerted.

\section{B. Ability to Integrate the Informatization Teaching Resources}

Nowadays, the informatization teaching resources are increasingly abundant. To improve the efficiency of resource utilization, we should integrate such teaching resources in a standard way to promote the information exchange and sharing. In informatization teaching, the resources requiring to be integrated include mobile learning ability, digital learning ability, etc. Specifically speaking, integration of education information resources refers to the process of converting the texts, pictures, video and other resources into network learning resources, so as to promote students' enthusiasm and creativity in learning, deepen students' learning ability and innovation consciousness and embody the theme of "autonomy, cooperation and inquiry" of informatization teaching.

The integration of informatization teaching resources should follow the principle of "unified planning, unified standard and adjustment according to local conditions and circumstances" [2]. Information resources can be integrated into different forms such as special subject study network, personal website or blog, excellent courses, online courses and online teaching platforms. The ability to integrate the informatization teaching resources can be developed according to the following methods: the school can establish a reasonable evaluation and incentive mechanism to encourage teachers to develop such; make full use of education technology project to finance teachers in the integration of education resources; provide training in integration of informatization teaching resources for teachers to improve their information accomplishment; establish a special sharing area of public education information resources.

\section{Ability to Implement the Informatization Teaching}

The most critical and core part of informatization teaching is the implementation. The implementation of informatization teaching should focus on the practice of informatization teaching, because this is an area where teaching grows and the reflection thereinto is the source of the development of teachers' informatization teaching ability. Therefore, in the implementation of informatization teaching, teachers should attach importance to the practice and reflection.

The informatization teaching ability is incongruous with the actual teaching environment and conditions, that is, the actual teaching conditions and environment cannot fully satisfy the smooth implementation of informatization teaching, and the transformation of this ability is based on teaching practice. In the development of the implementation ability, the school shall guide teachers to improve the application of informatization teaching knowledge and skills through mimicking learning and transfer learning of education and teaching technology, information technology and subject pedagogy. The development of informatization teaching ability can facilitate the integration of informatization teaching knowledge system and informatization teaching practice. The implementation of informatization teaching is also an ongoing process, so in its implementation process, teachers shall apply the theory in the teaching practice, discard simple technicality, and in the teaching process, strengthen guidance for students and introspection to implement growth-type intelligence-based teaching practice. In the meantime, teachers shall attach importance to listening to deepen their understanding of teaching knowledge system and realize optimization of knowledge-ability conversion, and this also facilitates the generation of practical theory. In the process of introspection, teachers shall combine spontaneous introspection and training-induced introspection, combine real-time discussion and centralized communication and 
improve their ability of implementing informatization teaching based on "practice-introspection-practice".

\section{WAY TO OPTIMIZE THE INFORMATIZATION TEACHING ABILITY STRUCTURE OF MIDDLE SCHOOL TEACHERS}

\section{A. Strengthening the Training of Informatization Teaching Ability Structure and Continuing Professional Development of Middle School Teachers}

In China's informatization teaching at present, as China's education reform started relatively late, information technology and management theory in education are constantly updating and developing, which leads to increasing confusion about informatization teaching in China. Ability training and continuing professional development are effective methods to solve the problem. However, the training for teachers in China is characterized by simplex method and no unified standard, leading to unsatisfactory training result, which restricts the further development of informatization teaching. Therefore, it is necessary to formulate an unified standard in ability training and continuing professional development.

In terms the training subjects, first, the school is supposed to train the backbone teachers in informatization teaching. These teachers shall set a good example for other teachers and pass the professional training on, give overall training and guidance to other teachers and lead the teachers around them to practise and improve the informatization teaching in daily teaching activities so as to facilitate the overall improvement of informatization teaching.

\section{B. Carrying out Relevant Seminars to Deepen the Concept of Informatization}

To the informatization teaching ability, in addition to professional training, it is also required to extensively carry out teaching communication activities that is carrying out seminars about informatization teaching to deepen the concept of informatization teaching, to help teachers ideologically understand, promote and develop informatization teaching [3].

The method, concept and standard of informatization teaching are constantly developing and changing, so teachers and schools shall carry out regular communication and discussion to point out and solve the problems and deficiencies existing in the informatization teaching and put forward new ways for development of the informatization teaching. In this way, different teachers and schools can learn from each other's strong points to offset their weakness and jointly improve, so that each teacher can deeply recognize the concept of informatization teaching, practise the informatization teaching in daily teaching activities, so as to realize the integration and unification of the ideas and actions in terms of informatization teaching to develop informatization teaching from its essence. Seminars should be carried out regularly and at different levels to make the concept of informatization teaching throughout the whole teaching process of each teacher to ensure the comprehensiveness and depth in implementation of informatization teaching.

\section{Independent Learning to Optimize Professional Knowledge and Skills}

For middle school teachers, to improve their skills and teaching level, they have to learn independently to optimize their professional knowledge and skills. Only in this way can teachers form informatization teaching wisdom and ability with their own characteristics. In the subject teaching, teachers should seize the opportunity and try self-centered development mode, because this is an important channel for teachers to improve themselves. In this background, informatization teaching ability is promoted in the organic unity of informatization teaching theory and practice. In addition, teachers, in the process of improvement, shall insist on constant practice and learning instead of giving up halfway and convert the informatization teaching ability into their cultural self-consciousness. Moreover, they also need to attach important to listening and summary to deepen their understanding of professional knowledge about informatization and promote their teaching ability.

To be specific, teachers may, on the one hand, apply to participate in the informatization teaching ability training and continuing professional development to expand horizons and deepen their understanding of the concept of informatization teaching; on the other hand, teachers may also actively discuss informatization teaching with colleagues around, share ideas with them and then implement these ideas in the classroom; last, with respect to independent learning, teachers may also summarize the deficiencies and problems existing in their teaching through communication with students, and gradually improve in the future informatization teaching, so as to constantly improve their informatization teaching ability.

In the wave of education informatization in China, middle school teachers are relatively lag behind in terms of teaching philosophy, and also have defects in informatization teaching ability. Therefore, optimizing the information teaching ability structure of middle school teachers has to start from the teaching philosophy, resources integration and teaching implementation ability and be realized by strengthening teaching training and continuing professional development, deepening the concept of informatization teaching and independently learning professional skills of informatization.

\section{CONCLUSION}

The information technology environment has created conditions for the improvement of middle school teaching level, and also posed challenges for the structural adjustment of middle school teachers' teaching ability. High school teachers need enhangce themselves through training or education, network research, so they will continuously learn new ideas, new skills, constantly absorbing the modern excellent teachers teaching methods, let oneself become the organizers of teaching, the mentor, the founder of learning resources, such ability in the development of the new age to become qualified middle school teachers. 


\section{REFERENCES}

[1] UNESCO, Ma Lan, Tang Yuxia. An Overview on "Information and Communication Technology Competency Standards for Teachers": Policy Framework, Competency Standards Modules and Implementation Guidelines [J]. Distance Education Journal, 2009(2):310 .

[2] Zhao Jian, Guo Shaoqing. Summary of Informationalization Teaching Ability [J]. Distance Education Journal, 2010(4):55-57.

[3] Mishra P. Teachers' Technological Pedagogical Content Knowledge and Learning Activity Types[J]. Journal of Research on Technology in Education, 2009, 41(4):393-416. 